\title{
Language policy and linguistic landscaping in a contemporary blue-collar workplace in the Dutch-German borderland
}

\section{Daan Hovens ${ }^{1}$ (D)}

Received: 7 April 2020 / Accepted: 19 November 2020 / Published online: 21 January 2021

(c) The Author(s) 2021

\begin{abstract}
This article argues that an expanded view of linguistic landscapes provides a useful metaphor for exploring language policies. Following this view, "language policy" is defined as "linguistic landscaping" (i.e., placing language policy mechanisms which, together with already placed mechanisms, construct a metaphorical landscape). The application of this landscaping metaphor has several advantages, as it provides a way to imagine language policy as a continuously ongoing construction process, and as it provides a way to imagine the historical layers of a landscape, the overlap and connections between different landscapes, and the complex hierarchical positions within a landscape. The article is based on linguistic-ethnographic fieldwork in a metal foundry in the Dutch province of Limburg, within walking distance from the Dutch-German border. Specifically, it discusses why a group of senior production workers from Limburg were dissatisfied with the linguistically diverse landscape that had emerged in the foundry over time, even though the foundry's management tried to place Dutch-speaking workers in the company's sociolinguistic norm centre. Confirming the usefulness of the landscaping metaphor, the article shows that a full consideration of diverse historical and contemporary acts of both linguistic and semiotic landscaping helps explain why these workers experienced that their position in the foundry had become peripheralised over time. In conclusion, the article calls for more attention to the complex human experience, rather than just the detection, of sociolinguistic inequalities.
\end{abstract}

Keywords Language policy $\cdot$ Linguistic landscape $\cdot$ Centre-periphery $\cdot$ Blue-collar workplace $\cdot$ Cross-border region $\cdot$ Power

Dit artikel beargumenteert det 'n breijer begrip van linguïstische langksjappe (linguistic landscapes) 'ne broekbare metafoor versjaf veur 't explorere van taalpolitiek. Dit perspectief volgend, wuuerdt "taalpolitiek" gedefinieerd es "linguïstisch langksju-

Daan Hovens

d.hovens@maastrichtuniversity.nl

1 Faculty of Arts and Social Sciences, Maastricht University, Maastricht, The Netherlands 
ppe" (linguistic landscaping), det wul zegke, 't plaatse van taalpolitieke mechanismes die, same met reids geplaatste mechanismes, "n metaforisch langksjap construere. De toepassing van deze "langksjuppe"-metafoor haet versjillende veurdeile, umdet 't veurzeet in "ne menier um taalpolitiek es " $n$ continu doorgaond constructieproces veur te sjtelle, en umdet 't veurzeet in 'ne menier um de versjillende historische lage van ' $n$ langksjap, de euverlap en verbinginge tusse versjillende langksjappe, en de complexe hiërarchische posities in "n langksjap veur te sjtelle. 't Artikel is gebaseerd op taalkundig-etnografisch veldwerk in "ne metaalgeeterie in de Nederlandse provincie Limburg, op laupaafsjtand van de Nederlands-Duitse grens. Mier specifiek bediscussieert 't artikel de vraog weurum 'ne groep senior-productiemedewerkers oet Limburg ontevraeje waar met 't talig diverse langksjap det in de laup van d'n tied in de geeterie ontsjtaon waar, zelfs al probeerde 't management Nederlands-sjpraekende werknimmers in 't sociolinguïstische normcentrum van 't bedrief te plaatse. Es bevestiging van de broekbaarheid van de "langksjuppe"-metafoor, luuet 't artikel zeen det 'ne volledige besjouwing van diverse historische en contemporaine, talige en semiotische langksjup-handelinge help um te begriepe weurum dees werknimmers ervaarde det eure positie in de geeterie door d'n tied haer waar geperiferaliseerd. Es conclusie rup 't artikel op um mier aandach aan de complexe minselikke ervaring, in plaats van allein de detectie, van sociolinguïstische ongeliekhede te besjtaeje.

Keywords taalpolitiek · linguïstisch langksjap · centrum-periferie · arbeiderswerkplaats $\cdot$ grensregio $\cdot$ macht

\section{Introduction}

This article is a linguistic-ethnographic study of language policy in a metal foundry in the Dutch province of Limburg, located within the Dutch-German borderland. Blue-collar production workers, including migrant workers, commute to the foundry from various places of residence in the Netherlands and Germany. Here, they encounter diverse spoken languages, including Dutch, English, German, and local varieties from Limburg (hereafter: Limburgish; Cornips 2013), as well as Arabic, Polish, Russian, and Turkish, among others.

The article tracks the historical emergence of this diverse (socio)linguistic constellation, as well as the language-political responses from the foundry's management over time, and explores the dissatisfaction with these developments among a group of senior production workers from Limburg, who typically spoke Dutch and Limburgish as their first languages. It shows that, although the management tried to place Dutch-speaking workers in the foundry's sociolinguistic norm centre (Pietikäinen and Kelly-Holmes 2013), many senior production workers from Limburg experienced the changes as a process of peripheralisation, and as a loss of workplace dignity (Lucas 2011). More specifically, I argue that a metaphorical way of understanding language policy as "linguistic landscaping" helps to describe and explain these findings. 
In doing so, I draw on previous research about language policy in blue-collar workplaces, where the term "blue-collar" refers to workers in places as diverse as construction sites (e.g., Theodoropoulou 2019), fish-processing plants (e.g., Holm et al. 2019), and cleaning companies (e.g., Gonçalves and Schluter 2017; Holm et al. 2019). In this body of research, much (but not all) blue-collar work is also described as involving a temporary basis and low social status (Lønsmann and Kraft 2017: 138). In addition, blue-collar work is typically regarded as physically demanding. With regard to language practices, many authors have observed that people in blue-collar workplaces often use other languages than the official or majority language of the nation-state in which they are working (Goldstein 1997; Gonçalves and Schluter 2017; Holm et al. 2019; Hiss 2017; Hovens 2020; Kraft 2019; Piller and Lising 2014; Theodoropoulou 2019). Besides this, the ability to use English as a lingua franca cannot be taken for granted here (see, e.g., Lønsmann 2014).

Occasionally, employers may explicitly prefer to recruit blue-collar workers who speak a particular migrant or minority language, due for example to certain stereotypes about a particular group, or the dependency this may create on a bilingual manager as a broker (Gonçalves and Schluter 2017). More commonly, however, studies show that the recruitment of migrant and/or minority workers occurs when there are not enough 'local' and/or majority workers who are willing to do certain blue-collar jobs, at least not for the wages provided (Duchêne 2011; Hiss 2017; Holm et al. 2019; Kraft 2019; Piller and Lising 2014). Furthermore, these studies show that for upward mobility in the company and the wider labour market, some degree of proficiency in the state's official or majority language(s), possibly in addition to English, is often required.

Several authors have pointed out that opportunities for blue-collar migrant workers to learn such 'valuable' languages, both inside and outside the workplace, are often limited, while the responsibility to learn these languages is often placed on them as individuals rather than on any institution (Holm et al. 2019; Kraft 2019; Piller and Lising 2014). Hiss (2017: 708) argues that linguistically assimilating migrant labour might be against a company's economic interests, as maintaining strong connections to their places of origins can facilitate the return of migrant labour if and when they are no longer needed. Duchêne (2011) further underlines the exploitative nature of companies profiting from migrant workers' multilingual skills (e.g., for translation services) without rewarding them. Nation-state ideology typically serves as a way to legitimise such sociolinguistic inequalities (Holm et al. 2019; Piller and Lising 2014). Other means of legitimation may be safety concerns (Kraft 2019, 2020) and evaluations of job interviews (Roberts 2013).

This article adds to these existing perspectives by focusing not on migrant workers, but on 'local' workers who are supposed to profit from existing sociolinguistic inequalities by being placed in the 'norm centre'. The 'local' workers I spoke with, however, did not seem to believe that they were 'profiting' at all. The article discusses why this was the case, and how the complex position of these workers can be described. In this way, the article contributes to the development of rich and nuanced perspectives on language policy and power in blue-collar work environments. 
The article starts with a theoretical framework, which centres around the terms "language policy" and "linguistic landscape". Afterwards, I present the broader historical-sociolinguistic situatedness of the Meuse-Rhine borderland where the foundry is located. I then briefly discuss my linguistic-ethnographic fieldwork data and methods. This is followed by an extensive presentation of these data, which leads to the final conclusion and discussion of the findings.

\section{Theory: language policy as linguistic landscaping}

In recent decades, the field of language policy studies has developed from being primarily concerned with language planning activities on the level of the nation-state, towards being increasingly interested in de facto language policies and practices that emerge in daily, situated interactions in, e.g., schools and workplaces (Tollefson and Pérez-Milans 2018: 7-8). An influential contribution has come from Spolsky (2004: $5)$, who added language practices and language ideologies to language planning as the three defining components of language policy. Shohamy (2006: 54) further added the component "language policy mechanisms" to this framework, highlighting the means through which ideologies are reproduced and practices emerge in daily interactions. Johnson (2013: 7-9), on the other hand, argued that it is unhelpful to conflate the notions of policy, ideology, and practice, and proposed instead to limit the definition of language policy to language policy mechanisms only.

More or less simultaneously, the field of linguistic landscape studies has developed from being primarily concerned with large quantitative explorations of the presence of certain language varieties on written signs in the public spaces of an entire nation or city, towards being increasingly interested in ethnographic explorations of how people interact with diverse semiotic signs in specific smaller-scale spaces such as a neighbourhood or a street (Shohamy 2019). Inspired by the work of Scollon and Scollon (2003), Blommaert (2013: 32-33) argued that the linguistic landscape should be understood as a historically, discursively organised space that typically provides certain norms for people who interact in it. Building upon posthumanist perspectives such as actor-network theory (Latour 2005), Pennycook (2019: 177-178) continued this line of thought and presented the notions of "agency" and "language" as distributed among the human and non-human actants (such as objects, smells, and space itself) that constitute the linguistic landscape (or, in his words, the "semiotic assemblage").

The simultaneous broadening of the two fields has made authors ask similar questions: "What isn't language policy?" (Johnson 2013: 9); "So, is everything linguistic landscape?" (Shohamy 2019: 80). While I agree with Johnson (2013) that it is helpful to define "language policy" more precisely as policy mechanisms, it is probably fine to leave the idea of a "linguistic landscape" as open and flexible as it currently is. The main reason for this is that, while the field of language policy is about a specific research topic (language policy), the linguistic landscape field has not so much evolved around a specific topic, concept, or theory, but more around a perspective or metaphor that guides particular ways of collecting and organising research data. It is about seeing the world in a spatially and historically organised way, and about 


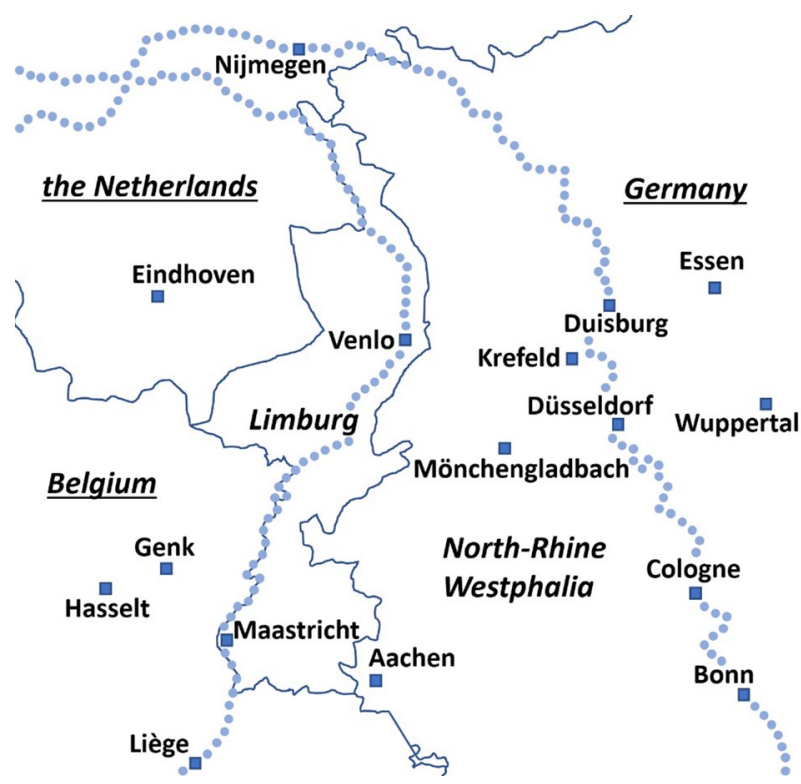

Fig. 1 Map showing the Meuse-Rhine borderland. The dotted line on the left represents the Meuse river flowing through the Dutch province of Limburg. The dotted line on the right represents the Rhine river flowing through the German state North-Rhine Westphalia (map created by author)

noticing the various actants that interact to produce this organisation. In principle, this perspective can be combined with many different research topics, concepts, and theories.

In this article, I explore the value of combining the linguistic landscape metaphor with Johnson's (2013) conceptualisation of language policy. This implies that I do not consider the linguistic landscape as one out of several language policy mechanisms (Shohamy 2006, 2015). Instead, I suggest that all language policy mechanisms can be regarded as different forms of linguistic landscaping in a concrete physical, as well as discursively constructed space. It is possible, for example, to regard policies about who can enter a nation, a school, or a workplace as acts of linguistic landscaping that may influence who can be (considered) part of the landscape (and who cannot). Similarly, it is possible to regard language education policies as acts of linguistic landscaping that may influence which linguistic resources become (considered as) part of the landscape. Furthermore, a wide range of other mechanisms that may impact "the structure, function, use, or acquisition of languages" (Johnson 2013: 9), such as the (re)production of policy texts, discourses, and written signs, can be regarded as acts of linguistic landscaping as well.

Imagining language policy metaphorically as "linguistic landscaping" has several advantages. First of all, by using a verb instead of a noun, the metaphor helps to imagine language policy as a constantly ongoing construction process or power struggle. Secondly, the metaphor helps to imagine that this construction process does not start from scratch, but that each policy agent (over and over again) faces an already shaped landscape, which the agent may affect by doing certain interventions 
(i.e., linguistic landscaping). Yet completely reshaping an existing landscape might be too ambitious, and various actants in the landscape might resist change. This relates to the third advantage, which is that the metaphor helps to imagine different, historically formed layers of the landscape (e.g., different language ideologies), which can still be influential today. Fourthly, the metaphor helps to imagine the landscape as (partly) overlapping with and connecting to other landscapes, and mobile organisms and artifacts might move in and out. Finally, the metaphor helps to imagine complex hierarchical relations in a multidimensional landscape, beyond binary oppositions such as 'here' and 'there', 'self' and 'other', or 'centre' and 'periphery' (see also Brambilla 2015: 22).

In the next sections, I explore how this metaphorical way of imagining language policy can be applied in a metal foundry and the Meuse-Rhine borderland.

\section{Linguistic landscaping in the Meuse-Rhine borderland}

The Meuse-Rhine border landscape in this article roughly refers to the Dutch province of Limburg and the German Rhine-Ruhr metropolitan region (which is part of the German state North Rhine-Westphalia; Figure 1). The political border that divides this area in a Dutch and a German part is relatively young. It was created around the year 1815, after the end of the Napoleonic Wars (Engelbrecht 1997). As I shall show this event was followed by significant language-political developments.

At the time that the border was created, the Meuse-Rhine border landscape was characterised by the West-Germanic dialect continuum: language varieties from towns that were geographically closer to each other were typically more similar than varieties from towns that were further away, regardless of the newly constructed Dutch-German border (Cornelissen 2015: 57-59; Giesbers 2008: 4-7). Furthermore, the use of standard Dutch, standard German, French, and Latin in different societal domains (such as the government, schools, and the church) did not follow the newly constructed territorial division either (Jacobs 2008).

After the creation of the border, diverse acts of linguistic landscaping aimed to establish standard Dutch as the official language in many domains on the Dutch side of the border, and standard German on the German side. An example of this is the spread of state-subsidised school textbooks in standard Dutch for German-speaking communities in Limburg (Jacobs 2008: 121). Furthermore, diverse policy acts have discouraged mobility between the Dutch and the German part of the border landscape since the second half of the $19^{\text {th }}$ century, including the introduction of a passport obligation for all foreigners staying in Germany during World War I (Korres 2006: 134). The decreasing cross-border mobility that followed went hand in hand with decreasing cross-border contacts, as Giesbers (2008: 63) has shown with regard to the relative share of Dutch-German marriages in five Dutch and five German towns in the Meuse-Rhine borderland, which strongly decreased between 1850 and 2000 .

The decrease in cross-border contacts may partly explain why traditional local varieties from the Dutch and the German part of the Meuse-Rhine border landscape 
have diverged linguistically from each other: the West-Germanic dialect continuum is now considered "broken" (Cajot 1996; Cornelissen 1995; Giesbers 2008). In most places on the German side of the border, traditional local varieties have even become nearly extinct (Cornelissen 2008, 2015; Giesbers 2008). This is partly due to the heavy industrialisation and the following migration of people who did not speak these varieties to the coal-rich areas of the Rhine-Ruhr region, which has resulted in the emergence of regional varieties (e.g., Ruhrdeutsch) that are relatively close to standard German, while they also have certain characteristics of both traditional and new migrant varieties (Cornelissen 2015: 131).

In the coal-rich south-eastern part of the Dutch province of Limburg, a similar sociolinguistic development has occurred on a smaller scale (Cornips 2003). Overall, however, traditional local varieties (known as "Limburgish") are still spoken by many people in the Dutch province of Limburg today, and they are often considered important markers of people's local and regional identities and solidarities (Cornips 2013; Cornips and Knotter 2016; Driessen 2006; Thissen 2018). Cornips and Knotter (2016: 163) describe the historical construction of Limburgish identity in the nineteenth and twentieth century as a process of "negative integration" or "integration through differentiation" in the Dutch nation-state, with which they mean that Limburgish identity emerged as an oppositional identity to the rest of the Dutch nation, while at the same time, 'being Limburgish' implied 'being Dutch' as well. This implication seems obvious to many people nowadays, even though Limburg was home to several separatist-minded individuals and movements up until World War II (Pabst 1992).

Today, many local and regional politicians, bureaucrats, and entrepreneurs in Limburg would like to get rid of certain (socio)linguistic traces that the linguistic landscaping efforts of the past have left, as they are obstacles for the political-economic ambition to create a cross-border labour market in the Meuse-Rhine borderland. The observed decreased interest in learning German among Dutch pupils (Duitsland Instituut Amsterdam 2018) has become a particular concern in this respect. In 2017, various politicians, bureaucrats, and entrepreneurs from Dutch-German and Dutch-Belgian border areas (including Limburg) formed the "Actieteam Grensoverschrijdende Economie en Arbeid" ("Action Group Cross-Border Economy and Labour"). In a report that this group presented to the Dutch government on 30 January 2017, it wrote the following (in Dutch) concerning language (Actieteam Grensoverschrijdende Economie en Arbeid 2017: 34):

Het actieteam stelt vast dat een gebrekkige kennis van het Duits een van de belangrijkste belemmeringen is bij het werken over de grens. De daling van het aantal leerlingen dat Duits op school volgt, is daarom een zorgelijke ontwikkeling. Schoolinstellingen, ouders en leerlingen moeten zich meer bewust zijn van het belang van kennis van de buurtaal en cultuur.

The action team observes that insufficient knowledge of the German language is one of the most important obstacles when it comes to working across the border. For this reason, the decreasing number of pupils who learn German at school is a worrying development. Educational institu- 
tions, parents, and pupils should be more aware of the importance of know-

ing the neighbour language and culture.

The use of the words "neighbour language and culture" confirms that nationstate discourses are deeply sedimented in the Meuse-Rhine border landscape, even among the members of this supposedly 'cross-border-minded' group. Apparently, from the presented Dutch border-regional perspective, the German language and culture are not part of an implicitly assumed 'self', but of a discursively constructed 'national neighbour'. Furthermore, the example shows that the economic urgency to promote the German language on the Dutch side of the border may be stronger than the urgency to promote Dutch on the German side.

The alarming discourse about the decreasing number of pupils learning the German "neighbour language", and its economic consequences, has entered regional news media in Limburg as well (see, e.g., Pollux 2019). Through such a stress on economic arguments, this discourse matches well with what Heller and Duchêne (2012) call "language in late capitalism". In this ongoing era, the authors write, "'pride' no longer works as well as the sole trope of nationstate legitimization; rather, the state's ability to facilitate the growth of the new economy depends on its ability to legitimize the discourse of "profit" (Heller and Duchêne 2012: 10). In the case of Limburg, the political challenge might be to legitimise the spread of German (and, possibly, other languages), as this seems economically profitable. However, a discourse of profit might lead to tensions with established, sedimented discourses of pride, for example, if students or employees in Limburg are told to speak German to help boost the regional economy, but their national pride stops them from doing so. In the remaining sections, I discuss how tensions between pride and profit play out in practice in a metal foundry in Limburg.

\section{Methodology and data}

My linguistic-ethnographic fieldwork in the production departments of the metal foundry lasted from 3 July to 15 October 2017. During this period, I participated in various work practices as an additional worker (e.g., by helping people lift heavy materials). At the end, I made 74 hours of audio recordings and 6.5 hours of video recordings of workplace interactions; I audio-recorded 11.5 hours of interviews with (former) workers and managers, as well as labour recruiters; I took 139 photographs of diverse signs, texts, and symbols; I wrote approximately 150 pages of fieldnotes, and I collected a wide range of other data.

This article is primarily based on the audio-recorded interviews and my fieldnotes. Furthermore, I have drawn extensively on different historical sources from and about the metal foundry, including: a book about the foundry's history and its founding father's biography, which his son published in 2018; one critical article about the foundry from a local labour party magazine from 1985; and a magazine that the foundry published to commemorate its anniversary in 2005. Combined with the interviews, these sources have helped me to reconstruct the 
company's history. Despite their immense value for my research, however, I have not included them in my reference list, in an attempt to protect the company's privacy. Although the foundry's management has allowed me to mention the company's name, I have decided not to do so, as this helps me to write more freely.

It was not possible for me to get explicit consent from every single employee before my fieldwork started. The foundry had around 500 employees, the turnover rate among them was high, and I regularly changed work teams in order to get a broad overview of the production process. Therefore, as approved by the Ethics Review Committee Inner City Faculties in Maastricht, I decided to work with implicit consent by hanging up a written announcement in Dutch, German, and English, as every production worker was supposed to understand at least one of these languages. Before making any recording, however, I still asked for people's explicit consent.

While doing interviews for my fieldwork, I had to consider which language(s) to use. With people who spoke Dutch and Limburgish as a first language (like me), I would usually speak Limburgish, as I felt that this established a more informal atmosphere. With people who did not speak Dutch or Limburgish, I would speak German or English (which I both speak as a second language). If I had spoken Dutch or Limburgish to them instead, I might have given the impression that I was testing their language skills, or that I was trying to implement a Dutch- or a Limburgish-only language policy. By speaking German or English, I tried to avoid this impression and to establish an informal atmosphere in these situations as well.

Finally, shortly before the start of my fieldwork (on 12 June 2017), two recruiters from a temporary employment agency that worked for the foundry warned me (in Limburgish) about a particularly vocal group of production workers, which they referred to with the Dutch words "oude garde" (and which I hereafter also refer to as the "old guard"). They told me that these senior workers from Limburg could be very critical about new developments in the foundry, and that it might be a challenge for me as a researcher to get socially accepted by them. In the end, I did not experience such problems, however. Rather than a target of criticism, several members of the old guard treated me as a potential messenger whom they could voice their opinions to. They would typically do so in Limburgish, and my choice to speak Limburgish might have helped this social situation to emerge. In the following sections, I discuss some of these opinions in more detail.

\section{Linguistic landscaping through labour recruitment practices}

The founding father's biography highlights the unprivileged labour-class environment of a small industrial town in Limburg in which he grew up. In 1945, after the end of World War II, he was in his early twenties. When he looked at the traces from the war in the Meuse-Rhine border landscape, his attention was caught by copper grenade bodies. He started to melt and mold them in a former goat stable at his parental house, and so the metal foundry was founded. Gradually, he built up a customer base, and by the time he retired in 1985, the foundry had more than 200 
employees and an annual revenue of more than 30 million Dutch guilders (approximately 15 million euros).

Finding enough employees for the foundry had been a challenge from the start. The founding father's way of dealing with this was simple but effective: he offered people a higher salary than other nearby industrial workplaces. Apparently, he did not believe that this would ruin his business, as has been observed in managerial discourse in other cases (e.g., Hiss 2017: 701). In 1955, he was even convicted in court for paying his employees more than the legal maximum wage (a post-war policy that was supposed to stimulate exports from the Netherlands). In this way, the foundry built up a reputation as a workplace where people could earn relatively much money, as long as they were willing to deal with its demanding and somewhat eccentric managers (i.e., the founding father and one of his friends). ${ }^{1}$ The founding father prided himself in being a hard worker, and he expected the same from his employees. He still participated in production work practices sometimes, and he did not shy away from criticising employees who did not perform well in his view. At the same time, he rewarded what he perceived as hard work, e.g., by giving people a free crate of beer. Employees with whom he had a good relation could get interestfree loans from him as well.

According to a critical article about the metal foundry from 1985, published in a magazine from a local labour party (in Dutch), only few of the foundry's employees were labour union members. The same article observed that the foundry did not employ any "foreigners". This was considered surprising, as many industrial companies in the Netherlands and Germany had recruited so-called "Gastarbeiter" ("guest labour") around the 1960s, which were labour migrants from Italy, Morocco, Spain, and Turkey (among other countries). As confirmed by his son during a (Limburgish) interview that I had with him on 18 October 2017, the founding father chose not to recruit any foreign labour during those years, as he managed to attract enough local labour due to the comparably high wages he offered. According to the labour party publication, not recruiting foreign workers was a "principle choice" from him, as they would cause "trouble". According to his son, he did so out of a concern for "communication problems". Whatever might be the reason, practically all of the foundry's employees from its early days until the 1980s were from the Dutch province of Limburg, and the dominant spoken language in the foundry was Limburgish.

When the founding father retired in 1985, his son succeeded him. The son had studied foundry engineering in the German Ruhr area, and had already worked in the foundry for more than 10 years before taking over his father's position. Under his management, the company continued to grow, and during the second half of the

\footnotetext{
1 Several senior production workers from Limburg mentioned the "high wages" reputation that the foundry used to have to me, including one worker whom I spoke with (in Limburgish) on 14 August 2017, one worker whom I spoke with (in Limburgish) on 28 August 2017, one worker whom I spoke with (in Limburgish) on 5 September 2017, and one worker whom I spoke with (in Limburgish) on 3 October 2017. The description "demanding and somewhat eccentric managers" is based on the founding father's biography, a Dutch article from a local labour party magazine from 1985 (see next paragraph), and two different (Limburgish) conversations that I had with elderly people who live nearby the foundry (but who never worked there), which took place around the start of my fieldwork in July 2017.
} 
Table 1 The number of production workers and other workers (e.g., HR managers, salespeople, and engineers) in the metal foundry, divided by citizenship, in August 2017

\begin{tabular}{llll}
\hline Citizenship & Production workers & Other workers & Total \\
\hline Dutch & $171(51 \%)$ & $159(99 \%)$ & $330(67 \%)$ \\
German & $89(27 \%)$ & $0(0 \%)$ & $89(18 \%)$ \\
Polish & $31(9 \%)$ & $0(0 \%)$ & $31(6 \%)$ \\
Other & $45(13 \%)$ & $1(1 \%)$ & $46(9 \%)$ \\
Total & $336(100 \%)$ & $160(100 \%)$ & $496(100 \%)$ \\
\hline
\end{tabular}

The presented figures are the sum of the data about all temporary workers in August 2017, which I have received as an anonymised Microsoft Excel file from one of the temporary employment agency's recruiters, and the data about the metal foundry's employees, which I have collected through email communication with an HR manager. As the HR manager filled in some gaps in the data from August 2017 with data from 2018, minor differences might exist between the actual figures and the figures presented here

1990s, the number of employees surpassed 400. The offered wages were now no longer sufficient to recruit Dutch- and Limburgish-speaking labour only. For the first time, the foundry's production departments opened up for German-speaking crossborder commuters, and for labour migrants who had originally come to the Netherlands as "Gastarbeiter", and who had learnt (some) Dutch as a second language since then.

The requirement that migrant workers had to speak Dutch seemed to be applied strictly at least in certain cases. For example, one production worker with a migrant background, whom I spoke with (in Dutch) on 30 August 2017, told me that he was turned down when he first applied for a job in the foundry in the 1990s, because his Dutch was deemed not good enough. Concerning cross-border commuters, some spoken German seemed to be tolerated, although one production worker from Germany who could speak Dutch, German, and a local variety told me on 12 September 2017 (using this local variety) that when he was recruited by the foundry in the late 1990s, the managers had explicitly told him that he was expected to speak Dutch, not German, at work.

That the recruitment of non-Dutch-speaking workers was a delicate issue, is shown by an article from a magazine that the foundry published in 2005. In this magazine, which appeared in Dutch, two Human Resource managers (hereafter: HR managers) wrote that "foreigners' ought to master the Dutch language sufficiently", because the mastery of this language would be "essential" when employees had to read written work instructions. Furthermore, they wrote that due to "the past", some workers would not or only insufficiently master the Dutch language. Therefore, the foundry had started to offer an annual Dutch language course, and the HR managers underlined that the company considered it very important that "employees take this course very seriously and finish it with a noticeable result". This discourse of linguistic assimilation matches well with the discourse on immigrant integration that became prominent in the Dutch political landscape in the early 2000s (see, e.g., Entzinger 2014). 
Finally, the global financial crisis of 2007-2008 led to a turning point in the company's history. Around the turn of 2008-2009, the demand for the foundry's products (i.e., metal components of trucks, luxury cars, and central heating boilers) dropped sharply. In February 2009, the founding father's son went with early retirement. A new Chief Executive Officer (hereafter: CEO) was appointed by the foundry's main shareholder. He was from the Dutch province of North Brabant and he spoke Dutch, but not Limburgish. Furthermore, he had no ties to the founding father and no previous working experience in the foundry. He was, as he wrote in the preface of the book about the company's history (in Dutch), a "beroepsmanager" ("manager by profession"). One of the first things that the new management did after taking office was to lay off more than 100 employees, which allegedly saved the foundry from bankruptcy.

Ever since this crisis, as the foundry's Chief Financial Officer (hereafter: CFO) explained to me (in Limburgish) in an interview on 4 December 2017, the management had become cautious with handing out new permanent contracts. By using temporary labour from employment agencies instead (Dutch: uitzendkrachten), the company could adapt more easily to (sudden) changes in the demand for its products. During my fieldwork in 2017, when the economy was blooming again, 196 out of 496 workers in the foundry (i.e., 40\%) were temporary workers. Most of the temporary staff worked in the production departments. Here, 185 out of 336 workers (i.e., 55\%) were temporary workers. At the end of my fieldwork, partly in response to criticisms from production workers about the lack of job security, the management decided to give 14 temporary workers a permanent contract.

The increased reliance on temporary labour from employment agencies meant a dramatic change for the foundry's linguistic landscape, especially during times of economic growth. The reason for this is that many temporary production workers who were recruited through employment agencies did not speak Dutch or Limburgish. Table 1 shows the number of production workers and other workers (such as salespeople) in the foundry in August 2017, divided by citizenship. The categories "Dutch", "German", and "Polish" may include first-generation immigrants who have obtained Dutch/German/Polish citizenship at some point in their life. In the following section, I discuss the acts of linguistic landscaping that emerged in the foundry in response to the increased language diversity.

\section{Linguistic landscaping and the construction of a 'Dutch' work environment}

The historical interest of the founding father's son is not just reflected by the book that he published about his father and the company. Under the son's management, the metal foundry was constructed as a place with a history, as the foundry's landscape was enriched with several commemoration stones, i.e., stones with engraved texts that commemorate the construction of a new wing of the foundry building, or the first official use of a new machine. Almost all of these texts were written in standard Dutch, following a somewhat standardised formulation: 'the first stone was 


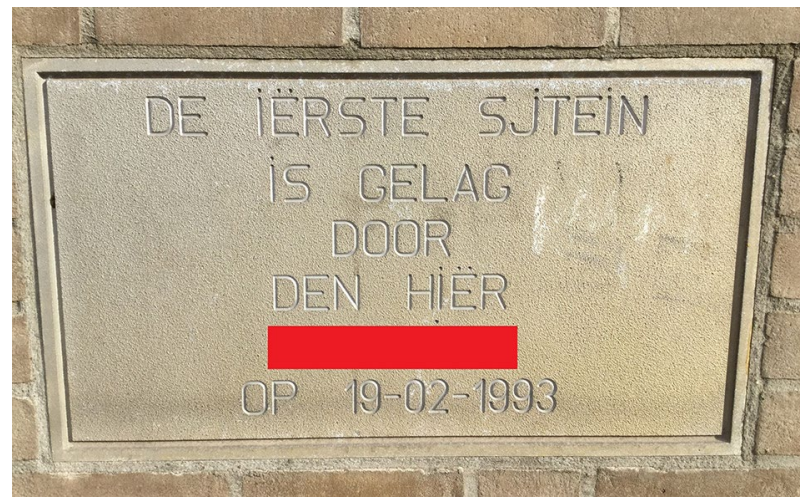

Fig. 2 Commemoration stone with Limburgish text, reading: "The first stone was placed by $\mathrm{Mr}$ [name anonymised by author] on 19-02-1993"

placed by this specific person on this specific date'. An exception to this tendency is a commemoration stone that was placed on 19 February 1993 (Figure 2). This was the Friday before the carnival celebration, an annual tradition that is often considered a symbol of Limburgish identity (see, e.g., Cornips and De Rooij 2015; Thissen 2018). Therefore, the text on this specific stone is in Limburgish.

The placements of commemoration stones are not just acts of historical landscaping, but also of linguistic landscaping. These acts reproduce a familiar pattern in the linguistic landscape of Limburg, where standard Dutch is often used to construct formal, institutional, and authoritative situations, while Limburgish is typically used to construct situations characterised by informality, solidarity, and local and/ or regional identity (see, e.g., Cornips 2020; Thissen 2018). This pattern can be recognised in other ways as well. As discussed in the previous section, the dominant spoken language in the foundry until—at least—the 1980s was Limburgish. When it comes to written announcements and instructions, however, standard Dutch was used. Furthermore, standard Dutch—not Limburgish—was considered the language that "foreign" workers had to learn, as shown by the foundry's magazine from 2005 (see previous section).

During my fieldwork in 2017, spoken Limburgish was still used frequently among workers from the Dutch province of Limburg, but in many production work teams, Limburgish-speaking workers were not a numerical majority anymore. Arguably, German had become the most frequently spoken language in the production departments, as this was a lingua franca spoken and understood by practically all workers from Germany, by many workers from the Netherlands (excluding first-generation immigrants who had learnt Dutch, but not German as a second language), and by several (but not all) workers from Central and Eastern Europe.

With regard to written announcements and instructions, standard Dutch was still the dominant language in the foundry's landscape. Furthermore, when one of the foundry's directors gave a formal presentation for production workers, as I observed on 12 July 2017, solely standard Dutch was used. Due to linguistic proximity, standard Dutch was possibly more understandable for German-speaking workers 
(particularly those who had worked in the foundry for a longer time) than for workers who spoke neither Dutch nor German or Limburgish. Thus, production workers with limited knowledge of Dutch, German, and Limburgish were often linguistically excluded in the foundry.

Explicit explanations for the continued, exclusive use of written standard Dutch in the linguistic landscape were presented to me on 12 June, 3 July, and 7 August 2017, when I attended several guided tours and introductory presentations for potential or newly recruited production workers. While referring to written board announcements from the management, which were written in Dutch only, the tour guides or presenters told the participants that the management used 'Dutch only' because employees were expected to learn Dutch over time. The following quote (in German) from a tour guide (who spoke Dutch and Limburgish as his first languages, and German and English as his second languages) is an example of this:

Was Sie hier sehen, sind Publikationen von der Direktion, Abteilungsleiter, und so weiter, und so weiter. Das ist meistens auf niederländisch geschrieben. Warum? Weil die Direktion möchte ganz gerne, dass die Leute niederländisch lernen im Laufe der Zeit.

What you see here are publications from the management, head of department, and so on, and so forth. That is mostly written in Dutch. Why? Because the management would like it quite much when the people learn Dutch over time.

The tour guides and presenters did not explain how people were expected to learn Dutch, and they did not refer to the annual Dutch language courses that the foundry's management organised for certain production workers either. The implication thus seemed to be that learning Dutch was people's own responsibility.

Shortly before my first working day in the foundry (3 July 2017), I came across an explicit formulation of a language rule in the digital linguistic landscape of the foundry as well. The reason for this was that I had to take an online test to ensure that I was familiar with, among others, certain safety regulations. Possibly as a way to manage workplace safety in the linguistically diverse production departments (see Kraft 2020), the test was available in Dutch, English, and German. I decided to take the Dutch version. In this way, I encountered the following rule about language use:

Van iedere medewerker wordt verwacht dat hij/zij de Nederlandse taal (eventueel de Duitse taal) dusdanig beheerst dat de medewerker zich verstaanbaar kan maken. Ook collega's onderling worden geacht de Nederlandse taal te spreken.

From every employee it is expected that he/she masters the Dutch language (perhaps, the German language) sufficiently such that the employee can make him/herself understandable. Also colleagues among each other are expected to speak Dutch.

When I asked one of the labour recruiters who worked for the foundry about this rule during an interview in her office on 27 September 2017, she told me (in Limburgish) that it was outdated, and that they had forgotten to update it. The part that had to be changed, according to her, was that they had to write "the German or the 
English language" instead of just "the German language". She further added that since January 2017, the tight labour market had made the foundry's management accept the recruitment of people who did not speak Dutch or German, but who did speak English as a second language. The updated language rule could thus be characterised as a normative expectation from the management to speak Dutch at work, although German and English (and, implicitly, Limburgish) were more or less 'tolerated'.

While observing language practices in the foundry's landscape during my fieldwork in 2017, I noticed that 'tolerating' German and English could mean different things. For the foundry's management, as discussed previously, it clearly meant that only Dutch was used for written announcements and instructions, and for formal presentations, while German and English were 'tolerated' for informal, spoken communication at work. When labour recruiters from the temporary employment agency would write a general email or announcement for production workers, on the other hand, they would typically do so in three languages: Dutch, German, and English. The order can be taken as a reflection of the language hierarchy and the chronological order in which the languages became 'accepted' in the production departments. Besides this, the more multilingual practices from the labour recruiters can be taken as a reflection of the idea that German and English were 'tolerated' as long as someone had a temporary contract, but that the norm to speak Dutch became stricter in case someone became permanently employed.

Nonetheless, in daily work practices, many permanent workers would speak other languages (such as German, Limburgish, and English) as well. Hence, the placement of Dutch language signs, formal Dutch presentations, and explicit Dutch language norms in the foundry's landscape did not affect most actual speaking practices at work. Something similar can be said about the annual Dutch language courses that the foundry's management organised for certain, selected production workers (namely those who had shown an interest in learning Dutch and who were expected to stay in the foundry for at least the near future). As these courses did not include all non-Dutch-speaking workers, and as they only covered the beginners' level, they did not seem to make much difference for daily, informal language practices. According to the self-employed teacher, whom I spoke with (in Limburgish) on 22 November 2017, it was not realistic to expect that participants would be fluent in Dutch after finishing the course. Rather, she said, I should view the courses as an "encouragement" to invest in learning Dutch.

Put differently, the Dutch language courses could be considered another act of linguistic landscaping through its signification of which production workers were expected to accommodate linguistically, and which ones were supposed to be the sociolinguistic norm centre in the foundry's landscape. Hence, despite all the changes in the foundry's recruitment and informal language practices, the old guard (i.e., senior Dutch- and Limburgish-speaking production workers who had started working in the foundry under the management of the founding father or his son) could still be considered as (part of) the top of the company's sociolinguistic hierarchy. Even so, many of them were quite critical about the linguistic landscape that had emerged over time. In the next section, I discuss in more detail why this was the case. 


\section{Linguistic landscaping and the position of the "old guard"}

To understand the complex hierarchical position of the old guard in the metal foundry's landscape, it is useful to first consider why the foundry's management tried to place these workers in the company's sociolinguistic norm centre. Within the management, the CFO was considered ultimately responsible for labour recruitment practices and the related questions about language policy. During my (Limburgish) interview with the CFO, which took place in his office on 4 December 2017, he gave two reasons why the management preferred to have Dutch-speaking workers:

(...) um de doodsimpele rede det det in de communicatie met elkaar gemekkeliker is, en auk de binding met 't bedrief wat mekkeliker makt.

(...) for the very simple reason that this is easier during the communication with each other, and it also makes the bonding with the company somewhat easier.

Concerning the second reason, "bonding", the CFO elaborated:

De wöls toch gewoeën gaer det medewerkers zich [company name]medewerker veule en det ze 'n good geveul hebbe beej 't bedrief, en 'n good geveul hebbe beej de collega's, eh, en det is netuurlik gemekkeliker as-se met äör kens communicere en as-ze met elkaar kenne communicere, eh, det kump de werksfeer ten goede, det kump daomei auk de kwaliteit ten goede (...)

After all, you would simply like that employees identify as [company name]employees, and that they have a good feeling about the company, and a good feeling about the colleagues, eh, and that is of course easier if you can communicate with them and if they can communicate with each other, eh, that is beneficial for the atmosphere at work, and in that way for the quality as well (...)

Based on this interview, it appears that the management was quite concerned about processes of bonding among workers themselves, and between workers and the company, and it does not appear that the management was interested in destroying any solidarity between different ethnolinguistic groups of blue-collar workers (Hiss 2017: 708). At the same time, the interview shows that the management had a rather narrow perspective on what might lead to such bonding processes. From the CFO's point of view, it was self-evident that non-Dutch-speaking workers had to accommodate linguistically in order to facilitate communication and bonding processes in the foundry. Dutch-speaking workers (including the old guard) were not expected to contribute actively, and other possible bases for communication and bonding (such as English, German, Limburgish, Polish, or a mixture of languages) were not considered, which further confirms how deeply sedimented nation-state discourses had become over time.

As the management tried to place Dutch-speaking workers in the sociolinguistic norm centre, and as knowing Dutch would supposedly facilitate processes of bonding with the company, it might be expected that Dutch-speaking workers such as the old guard felt a relatively strong bond with the management. During my conversations with the members of the old guard, however, it turned out that the standard 
of bonding set by the foundry's founding father and his son was a difficult one to live up to. For example, one such member whom I talked with (in Limburgish) on 24 July 2017, told me how the former directors would regularly come and see how things were going in the production departments, and how they would shake hands with everyone after New Year's Eve. The same person, plus two other members whom I talked with (in Limburgish) on 14 August 2017, told me about an easter egg that production workers used to get from the management, a practice that apparently stopped recently. Furthermore, two more members of the old guard, whom I talked with (in Limburgish) on 11 September 2017, referred to the free crates of beer that people would occasionally receive from the former directors as a sign of appreciation for their hard work. Even the author of the critical article from the local labour party magazine from 1985 observed that the foundry's founding father was "highly regarded" by his employees.

Of course, salaries and employment conditions had changed over time as well. As discussed previously, the founding father had offered relatively high salaries, and had managed to attract almost exclusively Dutch- and Limburgish-speaking workers in this way. Allegedly, the foundry's salaries were still relatively high compared to other blue-collar workplaces in the Meuse-Rhine borderland in 2017, but not so high that many Dutch- and Limburgish-speaking workers could be convinced to come and work there. Furthermore, as discussed previously, the foundry was increasingly relying on temporary labour from employment agencies since the global financial crisis of 2007-2008 (when many of the old guard had been laid off), and the people who were recruited in this way often spoke neither Dutch nor Limburgish. For certain, the foundry's management still invested in certain rewards for its workers (such as free ice cream on a hot summer day), but in the eyes of the old guard, this was not enough.

For the members of the old guard I spoke with, it appeared that the acts of bonding, the salaries, the employment conditions, the lay-offs, and the recruitment of non-Dutch-speaking workers together constituted a holistic entity. As one member whom I talked with on 24 July 2017 told me, these things showed that people had less "respect" for production workers these days. One of the members I talked with on 14 August 2017 also said it was a lack of "respect" for production workers that explained why so many temporary workers with diverse language backgrounds were recruited these days. According to him, people did no longer recognise the "craftmanship" that was needed for their work. Therefore, they would think that high turnover rates and language diversity were no insurmountable obstacles for achieving satisfactory work results. In other words, many of the old guard seemed to feel that their "dignity" at work was threatened, i.e., their "inherent worth and value and/or being deserving of respect" (Lucas 2011: 354).

These observations have important theoretical implications. The experience of belonging to a sociolinguistic norm centre, as opposed to a periphery, may not be constituted by the question whether people in a constructed periphery follow the language norms of a constructed centre (see, e.g., Pietikäinen and KellyHolmes 2013: 9), or by the question whether people in this centre gain more material profits than people in the periphery (see, e.g., Kraft 2019), even though 
these things all matter. First and foremost, however, the experience of belonging to a sociolinguistic norm centre may be one of deserving and receiving respect from others (regardless of whether these others are actors from a 'centre' or a 'periphery'), and an experience of having inherent worth and value. Moreover, these observations imply that the linguistic landscape cannot be isolated from a broader semiotic landscape (or "semiotic assemblage"; Pennycook 2019), and that linguistic landscaping acts cannot be separated from other acts of landscaping (e.g., the act of placing easter eggs in the landscape), as these acts may all influence people's subjective experience of workplace dignity.

For most members of the old guard, it was clear that the norm to speak or learn Dutch was and would not be followed much in practice in the production departments. Hence, the fact that the management continued reproducing this norm, and thus, continued reproducing a deeply sedimented nation-state discourse, was probably not beneficial for the management's credibility in the eyes of the old guard. Interestingly, despite the previously discussed, growing awareness of the importance of the German language for the economy of Limburg, the management did not try to legitimise the spread of German and other languages in the production departments through a discourse of profit (Heller and Duchêne 2012). In theory, for example, the management could have tried to argue that by allowing non-Dutch-speaking workers to enter these departments, the company could increase its production and make (more) profit, which might help the company (and the jobs it provided) to survive, and which might provide the management with more financial resources that could be invested in higher wages and more permanent contracts. In the end, the fact that the management did not produce such a discourse might have further contributed to the common feeling of peripheralisation among the old guard.

\section{Conclusion and discussion}

This article has explored the value of "linguistic landscaping" as a metaphor for describing the historically emerged language diversity and language policy mechanisms in the production departments of a metal foundry in the Dutch province of Limburg, and for explaining the dissatisfaction among the "old guard" (i.e., senior Dutch- and Limburgish-speaking production workers) with the emerged diversity and mechanisms. In this final section, I discuss three advantages of applying this metaphor.

The first advantage is the idea that a landscape has various, historically formed layers. Understanding the old guard's dissatisfaction requires taking into account these layers. To begin with, the foundry as a case shows how deeply sedimented the layer of Dutch nation-state ideology has become in Limburg over time. Within the global colonial landscape, this ideology legitimised the relative privilege of people who were considered part of the Dutch nation (as was indicated, among others, by Dutch being their first language). On top of this national-ideological layer, the foundry's founding father had built a layer of relatively exceptional privilege for Dutch- and Limburgish-speaking people who came to work in his 
company, and whom he offered relatively high wages. In this way, he had even managed to recruit practically no non-Dutch-speaking workers. During my fieldwork in 2017 , there were still many production workers in the foundry who had started working there under the management of the founding father or his son. This old guard had seen how things were different in the past, and hence, they did not accept the idea that the company could not help but rely on production workers from temporary employment agencies, who often did not speak Dutch.

The second advantage of "linguistic landscaping" as a metaphor is the idea that landscapes can (partly) overlap or connect with other landscapes. During my fieldwork, it became clear that the old guard's dissatisfaction concerned more than just the fact that the share of Dutch- and Limburgish-speaking workers had decreased over time. What they apparently appreciated about the founding father, was not just the high wages he offered and the fact that he did not employ non-Dutch-speaking workers (even though these things certainly mattered), but also his regular presence in the production departments, his regular interactions with production workers, and his regular signs of understanding and appreciating people's work. The fact that the founding father seemed proud of his own labour class background, and that he spoke Limburgish (i.e., the language of informality, solidarity, and local and/or regional identity) should not be underestimated in this respect. In short, the acts of linguistic landscaping were part of a broader practice of semiotic landscaping, which constructed a work environment in which the old guard felt they had a dignified position (Lucas 2011). This further implies that the arrival of non-Dutch-speaking production workers in the foundry's linguistic landscape can only partly explain the old guard's dissatisfaction in 2017, and that a broader repertoire or assemblage (Pennycook 2019) should be taken into account to understand why they felt that the company did not represent them anymore.

The third advantage of "linguistic landscaping" as a metaphor is the idea that diverse and complex hierarchical relations can exist in a multidimensional landscape (Brambilla 2015). The linguistic landscaping acts of the foundry's management clearly aimed at placing Dutch-speaking workers (such as the old guard) in the company's sociolinguistic norm centre. However, considering the observation that many production workers (including the old guard themselves) did not speak Dutch at work, and considering the abovementioned argument that the foundry's linguistic landscape was part of a broader semiotic landscape, it becomes clear that is too much of a simplification to present Dutch-speaking workers as the foundry's 'centre', and non-Dutch-speaking workers as its 'periphery'. Above all, this article has shown that inequality and exploitation are not necessarily given 'facts' that can be objectively detected or measured by a researcher, but subjective experiences based on various acts of linguistic and semiotic landscaping. Apparently, the old guard did not feel that they belonged to the company's periphery under the management of the founding father and his son, but they had started feeling so by 2017. From a linguistic-ethnographic perspective, it is valuable to understand why they experienced this change, and which acts of linguistic and semiotic landscaping have contributed to this experience of change. 
The findings discussed here have several implications. For researchers, the article is an invitation to further explore the potential of the linguistic landscape metaphor, and to pay more attention to the complex human experience (rather than just the detection) of inequality and exploitation. For managers, the article may serve as a source of inspiration for how to "bond" or establish relations of solidarity with employees such as the old guard. And last but not least, for employees such as the old guard themselves, the article may serve as a reminder that given constructions and subjective experiences in a particular time and space can never be taken for granted, as they are vulnerable to change over time. Hence, if possible, it may be best to become not too dependent on them.

Acknowledgements Writing this article would never have been possible without the cooperation from, and generous sharing of information and experiences by diverse actors in and around the metal foundry, including (former) directors and managers, employees, labour recruiters, as well as people living nearby the foundry. I would like to thank all of them wholeheartedly. Furthermore, I would like to thank Huiyun Cheng for the inspiring discussions on metaphors, landscapes, centres, and peripheries, which have clearly left some traces in my text. Finally, I would like to thank Leonie Cornips, Hans Schmeets, Jan ten Thije, Susanne Tienken, as well as John Harbord and two anonymous reviewers for their constructive feedback on earlier drafts. Particularly, I would like to thank one of the anonymous reviewers for suggesting to focus more on the "old guard". All remaining shortcomings are my own.

Open Access This article is licensed under a Creative Commons Attribution 4.0 International License, which permits use, sharing, adaptation, distribution and reproduction in any medium or format, as long as you give appropriate credit to the original author(s) and the source, provide a link to the Creative Commons licence, and indicate if changes were made. The images or other third party material in this article are included in the article's Creative Commons licence, unless indicated otherwise in a credit line to the material. If material is not included in the article's Creative Commons licence and your intended use is not permitted by statutory regulation or exceeds the permitted use, you will need to obtain permission directly from the copyright holder. To view a copy of this licence, visit http://creativecommons.org/licen ses/by/4.0/.

\section{References}

Actieteam Grensoverschrijdende Economie en Arbeid. (2017). Grenzen slechten, regio's verbinden, mensen bewegen. https://vng.nl/sites/default/files/publicaties/2017/170126_rapport_met_actie agenda_embargo.pdf.

Blommaert, J. (2013). Ethnography, superdiversity and linguistic landscapes: chronicles of complexity. Bristol: Multilingual Matters.

Brambilla, C. (2015). Exploring the critical potential of the borderscapes concept. Geopolitics, 20(1), 14-34.

Cajot, J. (1996). De Nederlands-Duitse staatsgrens als scheidingslijn tussen klanken, vormen en woordgeslachten. Paper presented at the 21st congress of the Vereniging voor Limburgse Dialect- en Naamkunde in Rolduc, Kerkrade on 18 November 1995. http://www.dbnl.org/tekst/cajo0 01nede01_01/cajo001nede01_01_0001.php. Accessed 5 June 2017.

Cornelissen, G. (1995). De dialecten in de Duits-Nederlandse Roerstreek: Grensdialectologisch bekeken. Mededelingen van de Vereniging voor Limburgse Dialect- en Naamkunde, 83. http:// www.dbnl.org/tekst/corn022dial01_01/corn022dia101_01_0001.php Accessed 5 June 2017.

Cornelissen, G. (2008). Meine Oma spricht noch Platt: Wo bleibt der Dialekt im Rheinland?. Cologne: Landschaftsverband Rheinland.

Cornelissen, G. (2015). Kleine Sprachgeschichte von Nordrhein-Westfalen. Cologne: Greven Verlag.

Cornips, L. (2003). Heerlens Nederlands. The Hague: Sdu. 
Cornips, L. (2013). Recent developments in the Limburg dialect region. In F. Hinskens \& J. Taeldeman (Eds.), Language and space: An international handbook of linguistic variation. Volume 3: Dutch (pp. 378-399). Berlin: De Gruyter.

Cornips, L. (2020). The impact of preschool attendance on children's bidialectism in the Netherlands: Why toddlers may stop speaking a regional language (Limburgish) at home. Language in Society, 49(3), 333-355.

Cornips, L., \& De Rooij, V. (2015). Belonging through languagecultural practices in the periphery: The politics of carnival in the Dutch Province of Limburg. Anthropological Journal of European Cultures, 24(1), 83-101.

Cornips, L., \& Knotter, A. (2016). De uitvinding van Limburg: De territorialisering van geschiedenis, taal en identiteit. Maastricht: Sociaal Historisch Centrum Limburg.

Driessen, G. (2006). Ontwikkelingen in het gebruik van streektalen en dialecten in de periode 19952003. Toegepaste Taalwetenschap in Artikelen, 75, 103-113.

Duchêne, A. (2011). Néoliberalisme, inégalités sociales et plurilinguisme. L'exploitation des ressources langagières et des locuteurs. Langage et société, 2(136), 81-108.

Duitsland Instituut Amsterdam. (2018). Schoolvak Duits: Feiten en cijfers. https://duitslandinstituut. nl/naslagwerk/1223/feiten-en-cijfers Accessed 19 January 2020.

Engelbrecht, J. (1997). Räume und Grenzen in historischer Perspektiv: Die Entwicklung der deutschniederländischen Grenze im Wandel der Jahrhunderte. Dorenburg: Museumsverein.

Entzinger, H. (2014). The growing gap between facts and discourse on immigrant integration in the Netherlands. Identities, 21(6), 693-707.

Giesbers, C. (2008). Dialecten op de grens van twee talen. PhD dissertation, University of Nijmegen. https://repository.ubn.ru.nl/bitstream/handle/2066/67849/67849.pdf?sequence=1 Accessed 5 April 2020.

Goldstein, T. (1997). Two languages at work: Bilingual life on the production floor. Berlin/New York: Walter de Gruyter.

Gonçalves, K., \& Schluter, A. (2017). "Please do not leave any notes for the cleaning lady, as many do not speak English fluently": Policy, power, and language brokering in a multilingual workplace. Language Policy, 16, 241-265.

Heller, M., \& Duchêne, A. (2012). Pride and profit: Changing discourses of language, capital and nation-state. In A. Duchêne \& M. Heller (Eds.), Language in late capitalism: Pride and profit (pp. 1-21). New York: Routledge.

Hiss, F. (2017). Workplace multilingualism in shifting contexts: A historical case. Language in Society, 46, 697-718.

Holm, A. E., O'Rourke, B., \& Danson, M. (2019). "Employers could use us, but they don't”: Voices from blue-collar workplaces in a Northern Periphery. Language Policy. https://doi.org/10.1007/ s10993-019-09513-4.

Hovens, D. (2020). Workplace learning through human-machine interaction in a transient multilingual blue-collar work environment. Journal of Linguistic Anthropology. https://doi.org/10.1111/ jola. 12279 .

Jacobs, A. (2008). Die Sprachverhältnisse in Niederländisch-Limburg, unter besonderer Berücksichtigung der kirchlichen Amtssprache. In W. Cortjaens, J. De Maeyer, \& T. Verschaffel (Eds.), Historism and cultural identity in the Rhine-Meuse Region: Tensions between nationalism and regionalism in the nineteenth century (pp. 113-136). Leuven: Leuven University Press.

Johnson, D. C. (2013). Language policy. Basingstoke: Palgrave Macmillan.

Korres, A. (2006). Paspoortregime en migratie in het Duits-Nederlandse grensgebied in de negentiende en twintigste eeuw tot ca. 1940. In A. Knotter \& W. Rutten (Eds.), Studies over de sociaaleconomische geschiedenis van Limburg L1 (pp. 117-144). Maastricht: Sociaal Historisch Centrum Limburg.

Kraft, K. (2019). Language policies and linguistic competence: New speakers in the Norwegian Construction Industry. Language Policy, 18, 573-591.

Kraft, K. (2020). Linguistic securitisation as a governmentality in the neoliberalising welfare state. In L. Martín Rojo \& A. Del Percio (Eds.), Language and neoliberal governmentality (pp. 29-48). London: Routledge.

Latour, B. (2005). Reassembling the social: An introduction to actor-network-theory. Oxford: Oxford University Press.

Lønsmann, D. (2014). Linguistic diversity in the international workplace: Language ideologies and processes of exclusion. Multilingua, 33(1-2), 89-116. 
Lønsmann, D., \& Kraft, K. (2017). Language in blue-collar workplaces. In B. Vine (Ed.), The Routledge handbook of language in the workplace (pp. 138-149). London: Routledge.

Lucas, K. (2011). Blue-collar discourses of workplace dignity: Using outgroup comparisons to construct positive identities. Management Communication Quarterly, 25(2), 353-374.

Pabst, K. (1992). Loyalitätsprobleme einer Grenzbevölkerung: Das Beispiel Niederländisch-Limburgs im 19. und 20. Jahrhundert. In H. Klueting (Ed.), Nation-Nationalismus-Postnation: Beiträge zur Identitätsfindung der Deutschen im 19. und 20. Jahrhundert (pp. 27-46). Cologne/Vienna/ Weimar: Böhlau Verlag.

Pennycook, A. (2019). Linguistic landscapes and semiotic assemblages. In M. Pütz \& N. Mundt (Eds.), Expanding the linguistic landscape: Linguistic diversity, multimodality and the use of space as a semiotic resource (pp. 156-184). Bristol: Multilingual Matters.

Pietikäinen, S., \& Kelly-Holmes, H. (2013). Multilingualism and the periphery. Oxford: Oxford University Press.

Piller, I., \& Lising, L. (2014). Language, employment, and settlement: Temporary meat workers in Australia. Multilingua, 33(1-2), 35-59.

Pollux, F. (2019). Duits mallotig? Engels - dá's pas pittig: chaotische uitspraak en spelling. Dagblad de Limburger, 9 August 2019. https://www.limburger.nl/cnt/dmf20190808_00117772/duitsmallotig-engels-da-s-pas-pittig-chaotische-uitspraak-en-spelling. Accessed 5 April 2020.

Roberts, C. (2013). The gatekeeping of Babel: Job interviews and the linguistic penalty. In A. Duchêne, M. Moyer, \& C. Roberts (Eds.), Language, migration and social inequalities: A critical sociolinguistic perspective on institutions and work (pp. 81-94). Bristol: Multilingual Matters.

Scollon, R., \& Scollon, W. S. (2003). Discourses in place: Language in the material world. London/ New York: Routledge.

Shohamy, E. (2006). Language policy: Hidden agendas and new approaches. London: Routledge.

Shohamy, E. (2015). LL research as expanding language and language policy. Linguistic Landscape, $1(1-2), 152-171$.

Shohamy, E. (2019). Linguistic landscape after a decade: An overview of themes, debates and future directions. In M. Pütz \& N. Mundt (Eds.), Expanding the linguistic landscape: Linguistic diversity, multimodality and the use of space as a semiotic resource (pp. 62-86). Bristol: Multilingual Matters.

Spolsky, B. (2004). Language policy. Cambridge: Cambridge University Press.

Theodoropoulou, I. (2019). Blue-collar workplace communicative practices: A case study in construction sites in Qatar. Language Policy. https://doi.org/10.1007/s10993-019-09518-z.

Thissen, L. C. Z. (2018). Talking in and out of place: Ethnographic reflections on language, place, and (un)belonging in Limburg, the Netherlands. Ph.D. dissertation, Maastricht University. https://cris. maastrichtuniversity.nl/en/publications/talking-in-and-out-of-place-ethnographic-reflections-onlanguage. Accessed 5 April 2020.

Tollefson, J. W., \& Pérez-Milans, M. (2018). Research and practice in language policy and planning. In J. W. Tollefson \& M. Pérez-Milans (Eds.), The Oxford handbook of language policy and planning (pp. 1-32). Oxford: Oxford University Press.

Publisher's Note Springer Nature remains neutral with regard to jurisdictional claims in published maps and institutional affiliations.

Daan Hovens is a Ph.D. candidate at Maastricht University. His research interests include language policy, workplace learning, and human-machine interaction in blue-collar work environments. His first academic publication has appeared in the Journal of Linguistic Anthropology (Hovens 2020). Daan holds a double M.A. degree in Euroculture from the Georg August University of Göttingen and Uppsala University. Furthermore, he holds a M.A. degree in Journalism, and a B.A. degree in Scandinavian Languages and Cultures from the University of Groningen. Prior to his Ph.D. studies, Daan worked as a journalist and web editor for the Dutch public broadcasting organisation VPRO. 